\author{
Asian Journal of \\ Medical and Biological Research \\ ISSN 2411-4472 (Print) 2412-5571 (Online) \\ www.ebupress.com/journal/ajmbr
}

\title{
Article \\ Arsenic deposition in different organs or tissues in an experimental toxicosis of White Newzealand Rabbit
}

Shaifuddin Ahmed ${ }^{1 \mathrm{a}}$, Md. Saiful Islam Siddiqui ${ }^{2 a^{*}}$, Kamrul Islam ${ }^{3}$, Md. Nazrul Islam ${ }^{4}$, Mohammad Usman $\mathrm{Gani}^{5}$, Sharifunnessa Moonmoon ${ }^{2}$, Md. Harun-or-Rashid ${ }^{6}$ and Md. Abdul Awal ${ }^{7}$

${ }^{1}$ Upazilla Livestock Office, Kulaura, Moulvibazar, Bangladesh

${ }^{2}$ Sylhet Agricultural University, Sylhet-3100, Bangladesh

${ }^{3}$ Upazilla Livestock Office, Kaligonj, Gazipur, Bangladesh

${ }^{4}$ DLS, Farmgate, Dhaka, Bangladesh

${ }^{5}$ Upazilla Livestock Office, Kotiadi, Kishoregonj, Bangladesh

${ }^{6}$ Upazilla Livestock Office, Singair, Manikgonj, Bangladesh

${ }^{7}$ Department of Pharmacology, Faculty of Veterinary Science, Bangladesh Agricultural University, Mymensingh-2202, Bangladesh

${ }^{a}$ Shaifuddin Ahmed and Md. Saiful Islam Siddiqui contributed equally to this work

*Corresponding author: Md. Saiful Islam Siddiqui, Sylhet Agricultural University, Sylhet-3100, Bangladesh. Phone: +8801712220335; E-mail: msisiddiqui2000@yahoo.com

Received: 16 August 2016/Accepted: 11 September 2016/ Published: 29 September 2016

\begin{abstract}
The present study was undertaken for the detection of arsenic in different organs or tissues in an experimentally induced arsenicosis affected adult Newzealand white rabbits. The experiment was carried out on a total of 30 ( 01 month old) adult Newzealand white rabbits. Experimental arsenicosis were developed in rabbits by oral administration of arsenic trioxide alone and along with tannic acid, di-sodium hydrogen phosphate (DSHP), alum and As contaminated water after filtration using SCIF bed along with alum. For this, the rabbits were randomly divided in to six (6) equal groups (A,B,C,D,E \& F) at the ratio of three males and two females in each group, rats of group A was kept as control without giving any treatment, rabbits of group B received arsenic trioxide@100ppm, group C received arsenic trioxide @ 100ppm plus tannic acid @ 100ppm, group D received arsenic trioxide @ 100ppm plus di-sodium hydrogen phosphate (DSHP) @ 100ppm, group E received arsenic trioxide @100ppm plus alum @100ppm orally daily for 60 days in all cases and group $\mathrm{F}$ received alum@100ppm in SCIF-bed filtrated water orally daily for 60 days. The different organs and tissues of both dead and sacrificed rabbits (Liver, kidney, heart, Lungs spleen, stomach, muscle and skin) were collected for detection of arsenic. Arsenic was detected qualitatively by Reinsch test, semiquantitatively by Merck Arsen test kit. The distribution of arsenic concentration was highest in liver and lowest in skin. It has been concluded that arsenic were deposited in different organs or tissues of rabbit in an experimentally induced arsenicosis as like as natural occurrence.
\end{abstract}

Keywords: deposition; detection; arsenic trioxide; tannic acid; DSHP; alum; SCIF-bed; organs; rabbit

\section{Introduction}

The peoples of Bangladesh have been suffering from serious public health problem arising from drinking arsenic contaminated ground water (Khalequzzaman et al., 2005). Nearly 62, out of 64 districts of the country's tube wells contain dangerous levels of inorganic arsenic, tube wells, which are serving as main sources of water for drinking and cooking purposes. People who are drinking this inorganic arsenic contaminated water are developing various pathological manifestations in their bodies (Saha, 1984). Manifestation starts from hyper 
pigmentation of the skin and mucous membrane and leads to death from mutation of cells in the body. The general populations are exposed to arsenic through drinking water, dust, fumes, and dietary sources. Arsenic is ubiquitous in the biosphere and occurs naturally in both organic and inorganic forms in water, food, soil, dust, wood and other materials (Friberg et al., 1986; Lau et al., 1987). Inorganic arsenic is more toxic than organic arsenical compounds and arsenic trioxide is more toxic than arsenic pentoxide (Clarke et al., 1981). Arsenic is stored mainly in liver, kidney and spleen, and most of it is excreted through urine and if the salt is not readily absorbed, much of it is eliminated in the feces (Selby et al., 1974). Chronic arsenic exposure in the range of 0.01-0.04 mg/kg/day has been associated with skin cancer in Taiwan (Huseh et al., 1995). Arsenic was present in meat and meat products, eggs, honey, milk and milk products, fresh water fishes, marine fishes and other marine organisms collected from Slovenia between 1985 and 1995 (Doganoc et al., 1997). Inorganic arsenic is considered as a human carcinogen with multiple sites of attack. There are numerous reports in the literature, based on past and ongoing experience in various countries in Asia and South America concerning the higher risks of skin, bladder, lung, liver and kidney cancer along with other non-cancerous health effects that result from continued consumption of elevated levels of As in drinking water (Chen et al., 1988; Guha Mazumder et al., 1998; Chowdhury et al., 2000a,b; Ferreccio et al., 2000; Berg et al., 2001). The influence of environmental pollution on human health can be determined in terms of biomonitoring of the metabolically inactive tissues, hair, and nails. Among many human tissues, hair, and nails are widely used as biomarkers of environmental burden of toxic metals (Agahian et al., 1990; Schegel-Zawadzka, 1992; Nowak, 1993; Chaudary et al., 1995; Das et al., 1995). The bioaccumulation of heavy metals like arsenic, lead and mercury in different organs or tissues in human and animals is rather a complex process and influenced by several factors, like environmental quality, age, sex (Chakraborti et al., 1998; Steinmaus et al., 2000; Aharoni and Tesler, 1992), nourishment, oxidation state of the metals and their binding sites (Wilhelm and Hafner, 1991; Schegel-Zawadzka, 1992) etc. In the context of the above situation, the present study was undertaken with a view to detect arsenic concentration in different organs or tissues in experimentally induced arsenicosis affected White Newzealand Rabbit.

\section{Materials and Methods}

\subsection{Experimental animals}

One month old thirty apparently healthy adult Newzealand white rabbits (Oryctolagus cuniculus) weighing between 250-450 g were purchased from a local private farm of Muktagacha, Mymensingh, Bangladesh and brought to the Experimental Pharmacology and Toxicology laboratory at Bangladesh Agricultural University (BAU) for the present study. After two weeks of acclimatization animals were segregated on the basis of their age and body weight without significant differences. They were housed throughout the entire period of study in well ventilated animal house at a room temperature of $23 \pm 1{ }^{\circ} \mathrm{C}$ and were supplied with standard ration formulated by ICDDRB, Dhaka and supplied fresh water ad libitum.

\subsection{SCIF -bed filtered water}

Sand-Charcoal-Iron-Filter (SCIF) bed was used as arsenic purifying system. The artificially As contaminated water was passed sequentially four times through SCIF bed. The filtrated water was collected and examined by using Merck Arsen test kit and was used in the study.

\subsection{Experimental chemicals}

The alum, tannic acid, activated charcoal (Merck KGa, Darmstadt, Germany), wood charcoal (kat koila), sand

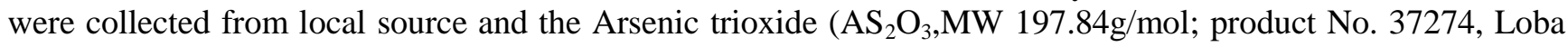
chemic pvt ltd, Mumbai, India), di-sodium hydrogen phosphate (Merck, India), iron oxide (BDH Lab., poole, England) were collected from Dhaka for this study.

\subsection{Experimental design}

The Rabbits were randomly divided in to 6 equal groups (A,B,C,D,E \& F) at the ratio of three males and two females in each group, rats of group A was kept as control without giving any treatment, rabbits of group B received arsenic trioxide@100ppm, group C received arsenic trioxide@100ppm plus tannic acid@100ppm, group D received arsenic trioxide@100ppm plus di-sodium hydrogen phosphate@100ppm, group E received arsenic trioxide@100ppm plus alum@100ppm and group F received alum@100ppm in SCIF-bed filtrated water orally daily for 60 days in each cases. 
2.5. Determination of arsenic trioxide in different organs or tissues of the body of rabbit

The different organs and tissues of both dead and sacrificed rabbits (Liver, kidney, heart, Lungs spleen, stomach, muscle and skin) were collected for detection of deposited arsenic in the different tissues and organs. Tissue homogenates were prepared as per following procedure.

\subsection{Preparation of tissue homogenate}

2-3 grams of the individual organs or tissues was grinded with the aid of pestle and mortar in demineralized water and then the tissue homogenates were taken in different test tubes placed on the rack. Demineralized water was added to the tissues at the ratio 4: 1 ( $4 \mathrm{ml}$ water $+1 \mathrm{gm}$ tissue $)$ for the preparation of tissue homogenates.

\subsection{Qualitative arsenic determination by Reinsch test}

The Reinsch test was based upon the fact that when moderately acid solution (weak HCL) containing ionized salts of arsenic, mercury were heated with metallic copper, these elements were deposited on the copper surface. Half dozens of copper wire cleaned with 1:4 nitric acid $\left(\mathrm{HNO}_{3}\right)$ and then washed with distilled water. $5 \mathrm{ml}$ of tissue homogenate as sample were taken in a $150 \mathrm{ml}$ of beaker. Six copper wire approximately half inch lengths were added in the beaker. 1:4 hydrochloric acid acid was then added to make the sample double. The mixture was allowed to be boiled gently with the help of an electric heater for about 30 minutes. The wires were obtained by decanting of the liquid and washed thoroughly by decapitation using distilled water then ethyl alcohol and finally by pure ether. The copper wire strips were then placed on a watch glass and dried at room temperature in a desiccators. If arsenic was present in the tissue homogenate the copper wire strips would be dark brown or black in colour.

\subsection{Arsenic determination by "Merck Arsen Test" kit (Semi- quantitative method)}

\subsubsection{Reaction principle}

The trivalent and pentavalent arsenic compounds in the solution to be tested are converted to arsenic by adding zinc and hydrochloric acid which turns the reaction zone, containing mercury (II) bromide in the head space above the solution, yellow to brown. Mixed arsenic mercury halogenides, e.g. As A2 $\mathrm{H} 2 \mathrm{HgBr}$ are formed.

\subsubsection{Materials required}

To estimate the concentration of arsenic by "Merck Arsen Test Kit" the following materials were used:

1. Analytical test strips

2. Reaction vessel

3. Plastic syringe

4. Measuring spoon

5. Reagent 1 (Zinc powder)

6. Reagent 2 (hydrochloric acid)

7. Samples to be tested (1gram tissue grinded in $4 \mathrm{ml}$ demineralized water).

\subsubsection{Procedure}

1. Holding the reaction zone of the test strip downwards, the test strip was inserted through slit in the cap of the reaction vessel, in such a way that the cap divides the strip into two approximately equal segments.

2. $5 \mathrm{ml}$ of the solution to be tested was transferred to the reaction vessel using the syringe; one measuring spoonful of reagent 1 was added and shaken.

3. 5 drops of reagent 2 was added and immediately the reaction vessel was closed with the cap.

4. It was left to react for 30 minutes, gentle swirling 2 or 3 times.

5. The test strip was removed, briefly dipped into water, shaken off excess liquid and compared the reaction zone with the colour scale and was multiplied by five.

\subsection{Statistical Analysis}

Collected data were statistically analyzed by the computer using statistical package programme MSTAT-C developed by Russel (1996). A one way ANOVA was made by F variance test.

\section{Results and Discussion}

\subsection{Determination of arsenic in tissue samples by Reinsch test}

The result of qualitative arsenic determination by Reinsch test was presented in Table 1. 
Table 1. Qualitative arsenic determination by Reinsch test.

\begin{tabular}{|c|c|c|c|c|c|c|}
\hline \multirow[t]{2}{*}{ Organs } & \multicolumn{6}{|c|}{ Groups } \\
\hline & $\mathbf{A}$ & B & C & D & $\mathbf{E}$ & $\mathbf{F}$ \\
\hline Liver & - & +++ & ++ & ++ & ++ & + \\
\hline Kidney & - & ++ & + & + & + & - \\
\hline Heart & - & + & + & + & + & - \\
\hline Spleen & - & + & + & + & + & - \\
\hline Stomach & - & ++ & ++ & + & + & - \\
\hline Intestine & - & ++ & + & + & + & - \\
\hline Lungs & - & + & + & + & + & - \\
\hline Muscle & - & ++ & + & + & + & - \\
\hline Skin & - & + & + & + & + & - \\
\hline
\end{tabular}

' - ' = Indicates absence of colour change of $\mathrm{Cu}$ wire in Reinsch test

' + ' $=$ Indicates mild colour change(blackish) of $\mathrm{Cu}$ wire Reinsch test

$'++$ ' $=$ Indicates moderate colour change(blackish) of $\mathrm{Cu}$ wire Reinsch test

$'+++$ ' $=$ Indicates severe colour change (blackish) of $\mathrm{Cu}$ wire Reinsch test

\subsection{Semiquantitative estimation of arsenic in tissue samples}

The semiquantitative estimation of arsenic in tissue samples were obtained by Merck Arsen Test which was presented in Table 2. In the present study the result of Reinsch test revealed that arsenic was distributed in liver, kidney, heart, stomach, spleen, intestine, muscle and dermis (skin). Moreover this study also revealed that storage of arsenic was the highest in the liver followed by kidney, heart, Lungs, stomach, spleen, intestine, muscle, and dermis (skin). Selby et al. (1974), Sahli (1982) and Proudfoot et al. (1991) reported that arsenic was stored mainly in liver, kidney and spleen in cattle and these findings were almost similar to the result of present study. The semi -quantitative estimation of the present study revealed that in group B the concentration of arsenic in the liver, kidney, heart, lungs, stomach, spleen, intestine, muscle, and dermis (skin) were 1.2, 0.8, $0.4,0.3,0.3,0.23,0.15,0.08$, and $0.06 \mathrm{mg} / \mathrm{kg} \mathrm{WW}$ which was in accordance the arsenic concentration found in duck and chickens naturally in Bangladesh in a study conducted by Islam et al.(2013) where arsenic concentration was $0.12,0.10,0.07$ and $0.05 \mathrm{mg} / \mathrm{kg} \mathrm{WW}$ in liver, kidney, intestine and thigh muscle respectively. McLennan and Dodson (1972) reported that a sample of rumen contents contained 4.5ppm $\mathrm{AS}_{2} \mathrm{O}_{3}$ and the cattle were suddenly died when they were grazing in a paddock containing a old sheep dipping vat. Krockza and Schuh (1973) reported that pig liver had the highest average content $(0.49 \mathrm{ppm})$ followed by pig muscle $(0.12 \mathrm{ppm})$. Pace et al. (1997) reported an incident of acute arsenic poisoning in two horses where liver arsenic concentration were 12.0 and $11.0 \mathrm{ppm}$ and a sample of renal context contained $108 \mathrm{ppm}$ arsenic. In the present study arsenic concentration found much more higher than the concentration observed by Krockza and Schuh (1973) and Pace et al. (1997) might be due to difference of mode of occurrence i.e natural or experimental case. The present finding revealed that, arsenic was highly distributed in various vital organs of rabbit of group B, because only $\mathrm{AS}_{2} \mathrm{O}_{3}$ was fed to this group. Arsenic was deposited in minor quantity in various organs of rabbit of group C, D and E. This might be due to the interaction of arsenic with tannic acid, DHSP and alum used in those groups along with arsenic trioxide. Arsenic was found only in liver of rabbits of group $\mathrm{F}$ in very minor quantity because of providing only SCIF bed filtered water and alum was added in vivo. In the recent period of time it was observed that presence of arsenic in food chain so, long term consumption of such contaminated food along with naturally As contaminated drinking water may play a significant contributory role to cause ailments of human health in arsenic prone area. 
Table 2. Mean concentration (mg/1000gm tissue) of arsenic in different tissues of rabbits following administration of arsenic trioxide along with tannic acid, DSHP, alum and effects of SCIF-bed filtrated water along with alum respectively.

\begin{tabular}{|c|c|c|c|c|c|c|c|c|c|c|}
\hline \multirow[t]{2}{*}{ Gr. } & \multirow{2}{*}{$\begin{array}{l}\text { Chemicals with dose \& } \\
\text { route }\end{array}$} & \multicolumn{9}{|c|}{ Samples } \\
\hline & & Liver & Kidney & Heart & Lungs & Spleen & Stomach & Intestine & Muscle & Skin \\
\hline$\overline{\mathrm{A}}$ & Control (untreated) & $\mathbf{0}$ & 0 & 0 & 0 & 0 & 0 & 0 & 0 & 0 \\
\hline $\mathrm{B}$ & $\begin{array}{l}\text { Arsenicosis control group } \\
\mathrm{AS}_{2} \mathrm{O}_{3} @ 100 \text { ppm orally }\end{array}$ & $1.2 \pm 0.0212$ & $0.8 \pm 0.02828$ & $0.4 \pm 0.0141$ & $0.3 \pm 7.071$ & $0.23 \pm 0.0212$ & $0.3 \pm 0.02828$ & $0.15 \pm 0.0141$ & $0.08 \pm 7.071$ & $0.06 \pm 0.01141$ \\
\hline $\mathrm{C}$ & $\begin{array}{l}\mathrm{AS}_{2} \mathrm{O}_{3} @ 100 \mathrm{ppm}+\text { Tannic } \\
\text { acid @ 100ppm orally }\end{array}$ & $0.32 \pm 8.944$ & $0.18 \pm 0.01788$ & $0.0126 \pm 4.472$ & $0.06 \pm 1.3416$ & $0.05 \pm 4.472$ & $0.054 \pm 4.472$ & $0.064 \pm 8.944$ & $0.03 \pm 4.472$ & $0.01 \pm 2.236$ \\
\hline $\mathrm{D}$ & $\begin{array}{l}\mathrm{AS}_{2} \mathrm{O}_{3} @ 100 \mathrm{ppm}+\mathrm{DSHP} \\
@ 100 \mathrm{ppm} \text { orally }\end{array}$ & $0.28 \pm 8.944$ & $0.13 \pm 1.3416$ & $0.01 \pm 4.472$ & $0.04 \pm 0.0313$ & $0.03 \pm 0.0268$ & $0.021 \pm 8.944$ & $0.051 \pm 0.0223$ & $0.01115 \pm 1.3416$ & 0.00 .0 \\
\hline $\mathrm{E}$ & $\begin{array}{l}\mathrm{AS}_{2} \mathrm{O}_{3} @ 100 \mathrm{ppm}+\text { Alum } \\
@ 100 \text { ppm orally }\end{array}$ & $0.16 \pm 8.944$ & $0.01 \pm 8.944$ & $0.08 \pm 0.134$ & $0.02 \pm 0.0223$ & $0.03 \pm 0.0268$ & $0.01 \pm 0.0134$ & $0.08 \pm 8.944$ & $0.01 \pm 4.472$ & 0.00 .0 \\
\hline $\mathrm{F}$ & $\begin{array}{l}\text { SCIF - bed filtrated water } \\
\text { + Alum @ } 100 \text { ppm orally }\end{array}$ & $0.001 \pm 0.0$ & $0.0^{* * *} \pm 0.0$ & $0.0^{* *} \pm 0.0$ & $0.0^{* *} \pm 0.0$ & $0.0^{* *} \pm 0.0$ & $0.0^{* *} \pm 0.0$ & $0.0^{* * *} \pm 0.0$ & $0.0^{* *} \pm 0.0$ & $0.0^{* *} \pm 0.0$ \\
\hline
\end{tabular}

Values given above represent the mean \pm SE of 5 rabbits

$*=$ Significance at $5 \%$ level $(\mathrm{P}<0.05)$

$* *=$ Significance at $1 \%$ level $(\mathrm{P}<0.01)$ 


\section{Conclusions}

It has been concluded that arsenic were deposited in different organs or tissues of rabbit in an experimentally induced arsenicosis as like as natural occurrence. Highest concentration of arsenic was observed in liver followed by kidney, heart, stomach, lungs, spleen, intestine, muscle and skin. So, in Bangladesh arsenic might be a threat in near future not only to human being also to livestock and poultry through different food chains which needs an extensive study.

\section{Conflict of interest}

None to declare.

\section{References}

Aharoni A and Y Tesler, 1992. Hair chromium content of women with gestational diabetes compared with nondiabetic pregnant women. Am. J. Clin. Nutr., 55: $104-107$.

Agahian B, JS Lee, HJ Nelson and RE Johns, 1990. Arsenic levels in fingernails as a biological indicator of exposure to arsenic. Am. Ind. Hyg. Assoc., J.51:646 -651.

Berg M, HC Tran, TC Nguyen, HV Pham, R Schertenleib and W Giger, 2001. Arsenic contamination of groundwater and drinking water in Vietnam: a human health threat. Environ. Sci.Technol., 35:2621 -2626.

Chowdhury UK, BK Biswas, T Roychowdhury, BK Mandal, G Samanta, GK Basu , CR Chanda, D Lodh, KC Saha, D Chakraborti, SC Mukherjee, S Roy, S Kabir and Q Quamruzzaman, 2000a. Arsenic groundwater contamination and sufferings of people in West Bengal-India and Bangladesh. In: Roussel AM, Anderson RA, Favier AE, editors. Trace elements in man and animals. New York: Kluwer cademicyPlenum Publishers, pp. $645-650$.

Chowdhury UK, BK Biswas, T Roychowdhury, G Samanta, BK Mandal, GK Basu, CR Chanda, D Lodh, KC Saha, SK Mukherjee, S Roy, S Kabir, Q Quamruzzaman and D Chakraborti, 2000b. Groundwater arsenic contamination in Bangladesh and West Bengal-India. Environ. Health. Perspect., 108:393 -397.

Chakraborti D, G Samanta, BK Mandal, T Roy Chowdhury, CR Chanda, BK Biswas, RK Dhar, GK Basu and KC Saha, 1998. Calcutta's industrial pollution: groundwater arsenic contamination in a residential area and sufferings of people due to industrial effluent discharge- an 8-year study report. Curr. Sci.,74: 346 -355.

Chen CJ, MM Wu, SS Lee, JD Wang, SH Cheng and HY Wu, 1988. Atherogenicity and carcinogenecity of high-arsenic artesian well water: multiple risk factors and related malignant neoplasms of black foot disease. Arteriosclerosis, 8: $452-460$.

Chaudary K, WD Ehmann, K Regan and WR Markesebery, 1995. Trace element correlations with age and sex in human fingernails. J. Radioanal Chem., $51-65$.

Clarke ML, DG Harvey and DJ Humphreys, 1981. Veterinary Toxicology. 2nd edn. ELBS, Bailiere and Tindal, p. 98.

Das D, A Chatterjee, BK Mandal, G Samanta, D Chakraborti and B Chanda, 1995. Arsenic in ground water in six districts of West Bengal, India: the biggest arsenic calamity in the world, Part 2. Arsenic concentration in drinking water, hair, nails, urine, skin-scale and liver tissue (Biopsy) of the affected people. Analyst, 120:917 $-924$.

Ferreccio C, C Gonza'lez, V Milosavjlevic, G Marshall, AM Sancha and AH Smith, 2000. Lung cancer and arsenic concentrations in drinking water in Chile. Epidemiology, 11:673-679.

Friberg L, GF Nordberg and VB Vook, 1986. Handbook on the toxicology of metals, 2nd edition, Elsevier Science Publisher, Amsterdam, New York, Vol. II, 1986, pp. 43-83.

GuhaMazumder DN, R Haque, N Ghosh, BK De, A Santra, D Chakraborty and AH Smith, 1998. Arsenic levels in drinking water and the prevalence of skin lesions in West Bengal, India. Int. J. Epidemiol., 27:_871 -877.

Hsueh YM, GS Cheng, MM Wu, HS Yu, TL Kuo and CJ Chen, 1995. Multiple risk factors associated with arsenic-induced skin cancer: effects of chronic liver disease and malnutrition status. Br.J. Cancer., 71: 109114.

Islam MS, MA Awal, M Mostofa, F Begum and M Myenuddin-, 2013. Detection of Arsenic in Chickens and Ducks. International Journal of Scientific Research and Management, 1: 56-62.

Khalequzzaman M, FS Faruque and AK Mitra, 2005. Assessment of arsenic contamination of groundwater and health problems in Bangladesh. Int. J. Environ. Res. Public Health, 2 : 204-13.

Krocza W and M Schuh, 1973. Arsenic residues in the carcasses of slaughtered animals. Vet. Bull., $44: 321$.

Lau PY, P Michalik, CJ Porter and S Krolik, 1987. Identification and confirmation of arsenobetaine and arsanocholine in fish, lobster and shrimp by a combination of fast atom bombardment and tandem mass spectrometry. Biomed. Environ. Mass Spectrom., 14: 723-732. 
Mclennan, MW and ME Dodson, 1972. Arsenic poisoning in cattle. Vet. Bull., 42:730.

Nowak B, 1993. Levels of heavy metals in the biological tests (hair, teeth) as an indicator of the environment pollution, in: International Conference-Heavy Metals in the Environment, Vol. 2, Toronto. pp. 408-411.

Pace LW, SE Turnquist, SW Casteel, PJ Johnson and RL Frankeny, 1997. Acute arsenic toxicosis in five horses. Veterinary Pathology, 34: 160-164.

Proudfoot FG, ED Jackson, HW Hulan and CDC Salisbury, 1991. Arsanilic acid as a growth promoter for chicken broilers when administerd via either feed or drinking water. Can. J. Anim. Sci., 71: 221-226

Russel D, 1996. MSTAT Director. Crop and Soil Science Department, Michigan State University, USA.

Saha KC, 1984. Melanokeratosis from arsenic contaminated tube-well water. Ind. J. Dermatol., 29 : 37-46.

Sahli BP, 1982. Arsenic concentration in cattle, liver, kidney and milk. Veterinary and Human Toxicology, 24: 173-174.

Schegel-Zawadzka M, 1992. Chromium content in the hair of children and students in Southern Poland. Biol. Trace Elem. Res.,32:79 -84.

Selby LA, AA Case, CR Dorn and DJ Wagstaff, 1974 . Public health hazards associated with arsenic poisoning in cattle. J. Am. Vet. Med. Assoc., $165: 1010-1014$.

Steinmaus C, S Nuñez and AH Smith, 2000. Diet and bladder cancer: a meta-analysis of six dietary variables. Am. J. Epidemiol., 151:693-702.

Wilhelm M and D Hafner, 1991. Monitoring of cadmium, cooper, lead, and zinc status in young children using toenails: comparison with scalp hair. Sci. Total Environ. 103:199 -207. 